\title{
Johannes Althusius' Grand Federalism, the Role of the Ephors and Post-Statist Constitutionalism
}

\section{P.E.R}

Pioneer in peer-reviewed, open access online law publications

Author

Koos Malan

Affiliation

University of Pretoria

South Africa

Email Koos.Malan@up.ac.za

Date published

5 Desember 2017

Editor Prof Klaus Beiter

How to cite this article

Malan K "Johannes Althusius' Grand Federalism, the Role of the Ephors and Post-Statist Constitutionalism" PER / PELJ 2017(20) - DOI

http://dx.doi.org/10.17159/1727-

3781/2017/v20i0a1350

\section{Copyright}

DOI

http://dx.doi.org/10.17159/17273781/2017/v20i0a1350

\begin{abstract}
This article discusses the primary structures Johannes Althusius' constitutionalism, as explained in his Politica: Politics Methodically Set Forth and Illustrated with Sacred and Profane Examples published in 1603. The first of these structures and the theme that Althusius is most famous for, is his scheme of grand republican federalism. The second is the public office of the ephors. The discussion is not primarily historical, however. The main aim, instead, is to assess the potential relevance of Althusius' thinking for present-day constitutionalism. After centuries of at best scant relevance owing to the dominance of the statist paradigm in constitutional doctrine and practice, the decline of this paradigm is now creating considerable new interest in Althusius' thinking.
\end{abstract}

The discussion starts off with a concise account of the statist paradigm, which was at its advent in Althusius' days. Thereafter follows an exposition of his federalism which consists of a set of associations, beginning with the closest-knit association, namely the family, spiralling out into the most encompassing association, which is the commonwealth or realm, with collegia, cities and provinces in between. The office of the supreme magistrate is dealt with under this heading. This discussion also focusses pertinently on the question of sovereignty, which in Althusian conceptualisation was a diffuse popular sovereignty in contrast to that of his statist opponents, more specifically Jean Bodin, and in posterity, Thomas Hobbes.

Then follows an assessment of the public office of the (council of the) ephors, which assists the supreme magistrate in executing his responsibilities in accordance with the law and the covenant between the commonwealth and the magistrate and serves a as counterbalance of authority and power against the sovereign.

Against this backdrop Althusius' constitutional thinking is evaluated. First, his constitutionalism is placed in historical context in contrast to (1) classical polis-based thought; (2) medieval imperial thinking and (3) modern statist constitutionalism. Secondly, Althusius' communitarian anthropology, which is in part the basis for his federalism, and which constitutes an anticipatory response to liberal individualism is assessed. Lastly it is argued that Althusius' federalism provides a valuable source for improving on the statedepartmentalisation of power separation and checks and balances, currently still sway in terms of the statist paradigm.

\section{Keywords}

Statist paradigm, State-departmentalisation, republican federalism, ephors, family, collegia, cities, provinces, commonwealth or realm, diffuse sovereignty, communitarian constitutionalism. 


\section{Introduction}

After centuries of being considered to be of at best marginal importance, considerable interest has of late arisen in the thinking of Johannes Althusius outlined in his 1603 work entitled Politica: Politics Methodically Set Forth and Illustrated with Sacred and Profane Examples. ${ }^{1}$ Over the past almost four hundred years our political and constitutional thinking and practice have been dominated by statism, which took shape within the framework set by the territorial state. Recently the dominance of the territorial state and statism have decreased considerably, thus making Althusius' comprehensive anticipatory alternative for a post-statist constitutionalism particularly informative. Althusian constitutionalism is expressed in his grand scheme of republican federalism.

Althusius' work is divided (acknowledging that these aspects of his work are closely interlinked) into the general tenets of his constitutionalism on the one hand and the structures of his constitutionalism on the other.

I refer in this article to Althusius' constitutional thinking or Althusius' constitutionalism, because Althusius conceived of a comprehensive constitutional order in which core constitutional concepts (as in constitutional discourse) such as the pursuit of justice, sovereignty, subsidiarity, federalism, control and balance of power, checks and balances, the notion of the mixed (and balanced) constitution and public office all enjoyed prominence. I state this preference fully realising that the terms constitution and constitutionalism were not known in the lexicon of the public, more specifically the political discourse in Althusius' times. The essential ingrerdients of constitutionalism as referred to in the present discussion are: the quest for a just polity; the notion of fundamentality, that is that the constitution (not necessairily in textual/written form) represents law of a higher status; the rule of law, mainly based on consensus; and the notion of the division - the diffusion - and the limitation and balance of power; and mutual checks and balances.

A previous discussion ${ }^{2}$ scrutinised these general tenets, namely Althusius's thinking on (1) piety, justice and community; (2) covenant (or contract); (3) supremacy of the commonwealth and of the law; and (4) political authority and public office. The main focus of the present discussion is the structural side of Althusian thinking, namely his system of republican federalism and the position of the ephors. (The meaning of the term ephors is discussed in detail in section 4 of this article.)

Koos Malan. BAHons (UP), Blur LLB LLD (UNISA). Professor of Public Law, University of Pretoria. Email: Koos.malan@up.ac.za.

Althusius Politica; Elazar "Althusius's Grand Design".

See Malan 2017 PELJ. 
Althusius' thinking represents the beginning of a counter-tradition in constitutional thought, sharply at variance with that which underpins the modern (territorial) statist tradition (or paradigm) of political thought (statism) as articulated by the founders (and latter exponents) of the statist tradition, namely thinkers such as Jean Bodin, Thomas Hobbes, John Locke, Jean Jacques Rousseau, Karl Marx ${ }^{3}$ and innumerable other followers who have been active within the confines of this paradigm. In order to develop a clear understanding of Althusius' thinking, it needs to be contrasted with statism, that is, with the statist paradigm which has dominmated political and constitutional thinking over the past almost four hundred years. In a previous discussion, on the general tenets of Althusius' thinking, the statist paradigm was dealt with in considerable detail. ${ }^{4}$ Hence, only a very brief account of statistm will be given in part 2 of the present discussion. Thereafter, in part 3, Althusius' federal scheme is discussed. The position of the ephors is dealt with in part 4 . The discussion concludes with a fairly extensive assessment of Althusius' place in political and constitutional theory, and this is followed by an appraisal of the value of Althusian thinking for contemporary constitutionalism.

\section{Statism}

The statist paradigm or statism has dominated modern constitutional thinking since the advent of the territorial state ${ }^{5}$ in the sixteenth and seventeenth centuries. Thus, the territorial state has defined the framework for political thought not only in academic disciplines such as constitutional law and political science, but also in public discourse in general. Statism also signifies that people adopt and cherish only one public identity, namely an individual identity in the image of the state, that is, a statist identity. ${ }^{6}$

Statism recognises only two entities, namely the state and the individual: the state is a centralised power apparatus maintaining the public peace among antagonistic individuals with no public identity other than their identity as citizens of the state, that is, other than their statist identity. Statism does not recognise or tolerate any other identity aside from a statist identity made up by the homogenised collection of all inhabitants of the state, and is antagonistic towards any community which is not a statist community. By the same token it rejects any apparatus of political authority apart from the state, or more specifically power apparatuses between the individual and the state. Such non-statist authority would be anathema to the statist paradigm since it is inimical to the very stability of the statist order itself. Statism proceeds from the

\footnotetext{
3 On this topic see Hueglin Early Modern Concepts 201; See also Malan 2014 Tydskr Geesteswet 462-480. 
premises of the fundamental absence of any real human community and of fundamentally antagonistic relations between abstract atomistic individuals combined with the state, as the centralised sovereign political force, encapsulated in the legislative, executive and adjudicatory apparatus which has to keep the public peace. All individuals are considered to be essentially the same, and any differences that might exist between them are held to be more apparent than real and politically of no moment.

Statism requires public identity to be monopolised for the benefit of the state. In consequence, only one community is recognised, namely a statist community comprising of all who find themselves within the boundaries of the territorial state and regardless of whether there exist any real bonds of culture, language, ethnicity or religion.

Thus viewed, the statist community is no real community at all but just a mass; any aggregate of persons or, in the words of John Locke, ${ }^{7}$ any number of men. In pursuance of statism there is a strict intolerance of any non-statist community, that is, any community of a cultural, linguistic, ethnic or religious nature which claims public recognition. In terms of a raft of programmes of homogenisation such communities are liquidated into a single uniform statist mass-society. To the extent that statism does tolerate such communities, they have to operate strictly in the private sphere, enjoying no public recognition or constitutional authority. In the final analysis the operative concepts of statist identity are homogenisation and uniformity - voluntary if possible, but forcible if needs be. ${ }^{8}$

Since statism recognises but a single centralised power apparatus, no power should be vested in any institution other than the power apparatus of the centralised state. Federalism, the devolution of power, the formation of communities or any other mechanism that could dilute the centralisation of power is opposed. To the extent that such mechanisms might in limited circumstances be tolerated, such toleration is basically an anomaly to statism.

The two elements of statism - the abstract individual with his statist identity and the centralised power apparatus of the territorial state - determine the way in which all matters of public life are conceptualised, these including crucial concepts such the constitution, constitutionalism, the rule of law and the Rechtstaat, sovereignty, citizenship, democracy, rights, and power.

$7 \quad$ Locke of Civil Government para 89. See the insightful comments on this by Van Dyke 1976-77 World Politics 343-369 and Van Dyke 1974 Am J Pol Sci 725-741.

8 It is significant to note that the onslaught on non-dominant communities prevails over the entire ideological spectrum - left, right and centre (liberal) as it were. The common denominator of all these anti-community trends is statism. In this regard see Malan 2014 Tydskr Geesteswet 462-480. 
The territorial state takes centre stage in statist thinking on constitutional law. In consequence the statist tradition also does not take any particular interest in political and constitutional thinking that does not share statism's fundamental assumptions. It is fixated on the state and the individual, thus ignoring and often justifying even pernicious policies for the destruction of communities ${ }^{9}$ and any other intermediary entity between the state and the individual or in place of the state. To the extent that it may be making concessions to such entities, it does so strictly within the confines of statist thinking. ${ }^{10}$

The statist tradition is distinctively positivist in that the existing territorial states have set the paradigm within which political and constitutional thinking have taken place over many centuries since the dawn of the territorial state. ${ }^{11}$ Moreover, the dominant concepts and themes of reflection in the field of constitutional law and political philosophy as well as in political practice are all statist in nature, that is, conditioned by and safeguarded for the territorial state. The accepted meaning of these concepts serves the specific needs of the territorial state. ${ }^{12}$

The thinking of Althusius is a distinctive alternative to statism. His thinking represents a wide-ranging world view which is the subject matter of his constitutional thinking. In this frame of thought Althusius synthesised the experience of the Holy Roman Empire with the political ideas of the covenant theology of Reformed Protestantism. ${ }^{13}$ He drew extensively from the Decalogue and other Biblical sources, ${ }^{14}$ and the philosophical, theological and juridical sources in the broader Roman Catholic tradition as it had emerged though the Medieval era. His thinking was also profoundly informed by Classical (non-religious) sources. Hence, he identified natural law with the second table of the Decalogue. ${ }^{15}$ Having drawn considerably from Aristotle, Althusius was also an Aristotelian par excellence. ${ }^{16}$ In the premises it may be asserted that Althusius was the quintessential Christian humanist, who amalgamated Christian doctrine and humanist thinking into a single (logically) comprehensive system of thought. The very title of his work bears the best testimony to that, because what he consistently and thoroughly did was in

$9 \quad$ Van Dyke 1974 Am J Pol Sci 726. See further Pestieau 1991 Can J Law Jurisprud 369370.

10 See for example the discussion of self-determination by Malan Politiocracy 246-267.

11 This is one of the main themes of Nisbet's discussion in his 1990 Quest for Community.

12 See for example Malan Politocracy 175, 197 and generally ch 5-9.

13 Elazar "Althusius's Grand Design" xxxv.

14 There are no less than two thousand quotations according to Hueglin's count. Hueglin Early Modern Concepts 56.

15 Sabine History of Political Theory 416-417. Althusius is in step here with a broad phenomenon of his time. Hugo de Groot had the same convictions. Also see De Benoist 2000 Telos 47-48. 
exact accordance with the title of his book, namely to methodically set forth and illustrate his politics with both sacred and profane examples.

Althusius' Christian humanist view also accounts for his rejection (in anticipation) of the modernist, more in particular the Hobbesian view of the essential absence of human community and the assertion instead that people are basically atomist, pursuing only their own interests and finding themselves fundamentally in a relationship of animosity with all other individuals. In contrast to the (individualist) nominalism, communities are in Althusius' view prior to individuals (individual members). ${ }^{17}$

Apart from being an exponent of the late medieval vision of society, Althusius may be viewed as an exponent of post-modern and post-statist federalism, which accounts not only for individual rights but also, very importantly, for the existence and claims of communities to which juridical and political rights must be attributed in the public sphere. ${ }^{18}$ Althusius exerted influence between the medieval and modern eras. He is quite justifiably considered as the person who discovered most of the key elements of federalism. ${ }^{19}$

The domination of statism has just about silenced the voice of Althusius for more than three centuries, but now that intellectual and material forces are causing increased pressure to bear upon the territorial state and on statism, Althusius is once again enjoying prominence on the stage of constitutional and political theory.

However, Althusius represents much more than that. His ideas set the basis for a tradition of constitutional thinking in direct opposition to the statist tradition in general. Not only were his ideas partly in direct opposition to those of Jean Bodin $^{20}$ but they also assumed the nature of a wide-ranging anticipatory response and present an alternative to the concepts that in time became fundamental traits of statism.

\section{The contours of Althusius' compound constitution of republican federalism}

Althusius is best known for his federalism. ${ }^{21} \mathrm{He}$ is in fact often viewed as the founder of the federal idea in modern political thinking. ${ }^{22}$ Federalism brings us

\footnotetext{
17 De Benoist 2000 Telos 32.

18 De Benoist 2000 Telos 54.

19 De Benoist 2000 Telos 54.

20 Althusius is in debate with Bodin at various places, eg Althusius Politica 72, 105, 130, $149,173$.

21 Even though he never used the word federalism himself - Hueglin Early Modern Concepts 2.

$22 \quad$ Elazar "Althusius's Grand Design" xxxvii.
} 
to the core of Althusius' constitutionalism. For two reasons it can be viewed as macro-constitutionalism because it deals not only with the workings of one part of the comprehensive constitutional order and commonwealth but also with the commonwealth as a whole, inclusive of all its composite elements, each with an integrity of its own. Federalism would best secure justice through the separation and balance of authority that has to be exercised in the interest of the whole of the citizenry.

Althusian federalism consists of a set of associations, beginning with the smallest association, namely the family, spiralling out into the most encompassing association, namely the commonwealth or realm (empire). Between the family and the empire are collegia, the cities and provinces, with the ecclesiastical associations also forming a distinctive part of the larger encompassing constitutional order. The order is built up from below, that is, from the smallest to the most encompassing entity, not the other way around. The smaller can still exist without the larger ones, but the more encompassing structures are not viable without the smaller ones. At the end of Politica Althusius declares as follows:

For this is the order and progression of nature, that the conjugal relationship, or the domestic association of man and wife, is called the beginning and foundation of human society. From it are then produced the associations of various blood relations and in-laws. From then in turn come the soladities and collegia, out of the union of which arises the composite body that we call a village, town or city. And these symbiotic associations as the first to develop can subsist by themselves even without a province or realm. However, as long as they are not in the united in the associated and symbiotic universal body of a province, commonwealth, or realm, they are deprived from many of the advantages and necessary support of life. It is necessary, therefore, that the doctrine of the symbiotic life of families, kinship associations, collegia, cities and provinces precede the doctrine of universal symbiotic association that arises from the former associations and is composed of them. In practice, however, all these associations are to be joined together for the common welfare of the symbiotes both individually and corporately. For the public association cannot exist without the private and domestic association. Both are necessary and useful in order that we may live advantageously. ${ }^{23}$

From this citation it is evident that Althusius' is a holistic but bottom-up constitutionalism ${ }^{24}$ that provides for the pluralisation of government among the members of a commonwealth in which all higher levels of authority are as a matter of principle constituted on the basis of consent from below. ${ }^{25}$ What Althusius set out to do was to develop a constitutional vision of a compound

\footnotetext{
$23 \quad$ Althusius Politica 207-208.

$24 \quad$ Hueglin Early Modern Concepts 129.

25 Hueglin Early Modern Concepts 153. Althusius' views on representation were consonant with his federal system. In line with the thinking of Marsilius of Padua he advocated what Hueglin Early Modern Concepts 136-151 described as an ascending and not a descending concept of representation.
} 
polity which would combine local autonomy and universal coordination ${ }^{26}$ local autonomy on the basis of subsidiarity, and universal co-ordination on the basis of solidarity. On the one hand he sought to maintain the autonomy of the plural order against the rising tide of territorialism and against contemporary theorists such as Jean Bodin. Autonomy, based on the principle of subsidiarity, ${ }^{27}$ was in fact the default, normal or standard position. At the same time, however, he conceived of a multitiered constitutional system - a community (the commonwealth) of multiple communities. The particular communities were sustained by consent among their constituent members, and the universal community - the commonwealth - was created and sustained from below, namely by the smaller communities. All communities were interconnected by universal principles of association, representation, and sovereignty. His system provided for shared or co-sovereignty that was divided up from the smallest fellowship to the universal commonwealth ${ }^{28}$ (in sharp contrast to the notion of unilateral and undivided state sovereignty of the incipient unitary territorial state). Accordingly, there should be balanced powersharing among different constituent communities. The particular interests are clearly autonomous but not sovereign on their own and somehow completely separated from other particular interests. They are bound together in the universality of the common enterprise, encapsulated in the encompassing commonwealth. Following the subsidiarity principle, all particular powers should be allocated at the lowest possible level of responsibility. At the same time, as Hueglin pointed out, these powers are still limited according to universal standards of solidarity. ${ }^{29}$

This line of thought has classical roots. It echoes the notion of the polis, active citizenship and self-government. At the same time it resonates with the medieval constitutional structure of Western Europe, with its wide variety of private and public associations and autonomous legal systems, which included the legal orders of the manors, feudal structures, rudimentary kingdoms, the cities, the church, and finally the empire, each having its own legal system and jurisdiction, ${ }^{30}$ but together making up one comprehensive worldly and spiritual whole (a totality), that is, one Republica Christiana. ${ }^{31}$ At the same time, it also accounts for the developments of Althusius' own times, such as the chasm in the Western church and the rising tide of territorialism which was bound soon

26 See Hueglin Early Modern Concepts 41.

27 Even though, as Hueglin Early Modern Concepts 152 noted, Althusius never used the term subsidiarity.

$28 \quad$ Hueglin Early Modern Concepts 61, 65.

29 Hueglin Early Modern Concepts 129.

$30 \quad$ See the wide-raging discussion by Berman Law and Revolution.

31 Or Reichskirchliche Weltganze (empire-church world whole) as it is has also been termed. 
to produce the unitary territorial state. In response to these developments Althusius proposed his federalism - the first ever comprehensive federal order.

The types of associations constituting the encompassing constitutional order are private on the one hand and public on the other. ${ }^{32}$ The first two associations, namely the family and the collegia, are private; the rest - the city (civitas), the province, up to the empire are public. All of them, however, each with its own integrity and jurisdiction, and each playing its own distinctive part in the larger constitutional order, are political in that the public associations are incapable of arising and enduring in the absence of the sound basis of private associations. ${ }^{33}$

\subsection{The family and collegia}

The family is a natural association based on necessity and affection. ${ }^{34}$ It should not be confused, however, with the modern nuclear family (a couple and their children; Afrikaans: gesin) but rather a broader association of kinship that includes more distant relatives, allies and friends, sharing similar characteristics. But why, one may tend to ask, are families politically significant; why are they essential in the constitutional order; and how can it be explained that they form part of the constitutional order, yet do not have a public nature? The answer to this question reveals a crucial element in Althusian constitutionalism. At the same time it marks a fundamental contrast with the modern constitutional order which recognises only two entities, namely the abstract individual and the sovereign territorial state. It also constitutes an answer in anticipation to the totalitarian politics that reared its head, first with the thinking of Rousseau and the Jacobins of the French Revolution. This totalitarianism culminated in the twentieth century Fascist and communist totalitarianism and in the modern-day benign human rights totalitarianism ${ }^{35}$ within the administrative state. Althusius noticed the first signs of this totalitarian peril, in terms of which everything, including the family and the collegia (broadly referring to commercial and civil society formations, as discussed below) is viewed to be public and therefore susceptible to subjection to centralised political control. That peril would fully materialise if the families and collegia as contemplated above would dissolve and be turned into atomised and vulnerable individuals, depending on an over-powerful political authority, namely the centralised and homogenising state, devoid of the protection and care that families once provided.

Althusius observed:

\footnotetext{
$32 \quad$ Althusius Politica 27.

$33 \quad$ Althusius Politica 27.

$34 \quad$ Althusius Politica 28.

35 Diamond "Rule of Law" 124.
} 
Furthermore, some persons wrongly assert that every symbiotic association is public, and none private. Now this axiom stands firm and fixed: all symbiotic association and life is essentially, authentically, and generically political. But not every symbiotic association is public. There are certain associations that are private, such is conjugal and kinship families, and collegia. And these are the seedbeds of the public association. Whence it follows that the private association is rightly attributed to politics. ${ }^{36}$

In Althusius' system families, and not individuals, are the seedbed for the larger public associations - the city, province and empire. ${ }^{37}$ Each family provides psychological, social and economic protection to its members allowing a semiautonomous (mutual) symbiosis within the family structure. It assigns a basic role and place to each of its members and each benefits from the physiological and economic protection generated by the collective contribution of all. In this way individuals are spared the vulnerable existence of being in a state of dependence on a distant and impersonal Leviathan, which has come to materialise in the modern state in which individuals have rights only vis a vis the state, which, depending on its strength and willingness, might or might not be enforced against the state. The family providing this protection enables its members to participate as self-reliant citizens in the public affairs of the bodypolitic - the city and larger public entities - instead of being the vulnerable dependent individual clients delivered to the actions of the centralised state. ${ }^{38}$

First, through the specialisation that they engender, collegia contribute towards the interests of the members of the collegium in question. This ensures a greater benefit for the whole of the body-politic, who benefit from the services and the good quality of life that comes with these services. At the same time it also enables people to concentrate on matters for which they are talented.

Secondly, collegia are self-governing entities. They do not owe their existence to some concession from a higher authority - they are not the useful tools for the exercise of sovereign power - they are self-generated and autonomous. ${ }^{39}$ There is no indication that a "higher" body (in contemporary politics, the state) may intervene in the affairs of the trade or profession in question and prescribe to collegia how such affairs should be administered. Hence, their selfgovernance over their own affairs is part of a larger strategy to ensure the

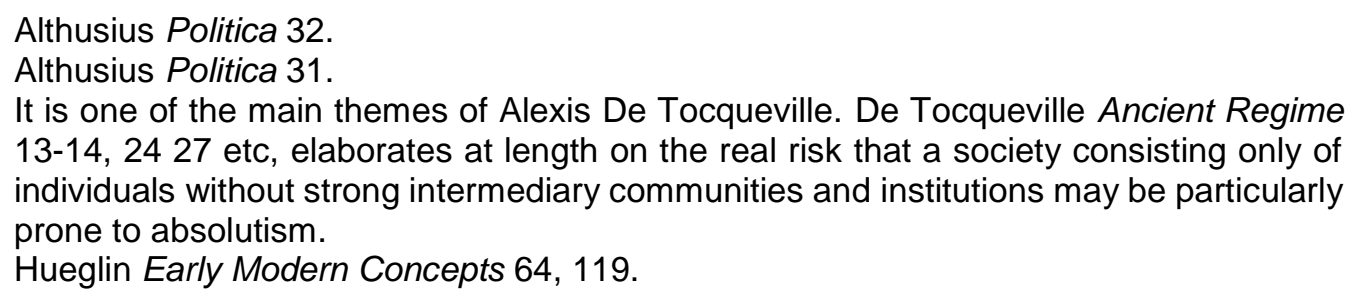
individuals without strong intermediary communities and institutions may be particularly prone to absolutism. 
limited government which is the backbone of the very idea of constitutionalism, since it fends off authoritarianism and promotes freedom. ${ }^{40}$

\subsection{The city (civitas) and the province}

In his discussion of the city and provinces, the concurrence of Althusius' particular political interests as a city politician of Emden, on the one hand, and his broad system of federalist theory, on the other, is at its strongest. He did not deal with cities from the distant perspective of an abstract theorist but in his capacity as an involved city politician resolute to defend the autonomy of Emden. Cities are one of the core elements in Althuius' federal system. He paid considerable attention to them and celebrated city life. The city stood at the centre of autonomous public life and was the foremost counterweight to the territorialism of the province - the germinating territorial state. ${ }^{41}$ Much of his attention he reserved for the celebration of city life..$^{42}$ Consonant with the subsidiarity principle of his federalism, cities should be autonomous, and obviously that autonomy was not to be based on some privilege or concession from above. It was not to be granted by the provincial or the imperial authorities, but on the autonomous rights of the citizen body. ${ }^{43}$

Cities are formed when many private associations are linked together. The importance of the city, more correctly the polis in Althusius' constitutional perspective, harks back to classical Greek politics. This is combined with the medieval empire but stands in stark contrast to the dominance of the territorial state (with its conglomerate of vulnerable individualised atoms), which has come to dominate modernist politics and statist constitutional doctrine. The city is the structure that provides the opportunity par excellence for public and political life among the symbiotes of the city - of citizens - to flourish to the full. The city is a permanent public association. It is not merely a gathering of any number individuals, nor a large crowd, mass assemblage or arbitrary throng of people. It is a way of symbiotic life of citizens according to the law of that city. ${ }^{44}$ Citizens are clearly distinguished from the peregrine, travellers etc (the non-

40 The importance of guilds resonates later with guild socialism and corporatism, both of which are strands in the movement of constitutional pluralism. Also see McRae 1979 CJPS 684-686.

41 Althusius did not use the term state or territorial state. The term state was at that stage not generally in use. The term "state" in the sense of territorial state was used for the first time in 1538 by Thomas Starkey but did not gain general acceptance. Later on it was used by Raleigh and Francis Bacon, as well as in the English translation early in the seventeenth century of Jean Bodin's work, and finally by Thomas Hobbes. Before that time terms such realm, body politic, commonwealth, common weal, civitas and republic signifying pre-statist entities were used. In this regard see Skinner "The State" 120-122.

42 Hueglin Early Modern Concepts 120, 142.

43 Hueglin Early Modern Concepts 44, 120.

44

Althusius Politica 39. 
citizens). ${ }^{45}$ The city includes the suburbs, outposts and villages. Apart from being joined together by the law of their city, citizens also share a raft of other common denominators - the same language, speech, discipline, customs and religion. ${ }^{46}$ We are dealing here with ideas which prevailed when Western Europe was still (Western) Christendom, ${ }^{47}$ that is, the era before religious tolerance was finally recognised, ${ }^{48}$ when religion was still a res publica on the same level as law. ${ }^{49}$ Citizenship was therefore still as much associated with a common religion as it was associated with a common legal order, customs, language, etc. In this regard Althusius states that persons who are openly and publicly atheists should not be tolerated. ${ }^{50}$ Neither was unbridled freedom of expression recognised. There was no tolerance for the promotion of "unnecessary wars" or for those who supported obscenities, that is, "shameful acts in public". ${ }^{51}$

Of paramount importance - and once again in sharp contrast to modernism's atomist individualism, is the fact that the city is a body of many diverse associations ${ }^{52}$ - families and collegia. It is not an arbitrary conglomerate of individuals. The city/citizen association must also be highlighted. Coming together in the city of families and collegia implied that the members of the private associations now assumed a completely new capacity. Now they were not spouses, kinsmen and colleagues as they were in their private associations but citizens of their city, more specifically not of the state. ${ }^{53}$ The etymological association of citizen with city in a number of languages (Afrikaans: burger with burg; German: Burger with Burg; French: citoyen with cite; Spanish: citadinos with ciudad) also underscores that the city and not the state or some other entity is the primary entity in the constitutional order.

The discussion of provinces did not appear in the original (1603) edition. Provinces as a third tier of consociation were added later in the face of the realisation of the growing role and importance of territorial politics. ${ }^{54}$ The

\footnotetext{
$45 \quad$ Althusius Politica 40; 48.

$46 \quad$ Althusius Politica 48. Althusius mentions even more common characteristics.

47 Pennington Seventeenth Century Europe.

$48 \quad$ This came about in the aftermath of the Protestant Reformation and more specifically as an outcome of the religious wars in France in the second half of the sixteenth century. See Malan Politocracy 74.

49 For example, as in the peace treaty of Augsburg of 1555, in terms of which the religious character of a principality was determined by its prince (cuius regio, eius religio), which determination provided for the ius emmigrandi of the subjects who did not identify with the chosen religion.

$50 \quad$ Althusius Politica 77.

$51 \quad$ Althusius Politica 77.

52 Althusius Politica 40

53 Althusius Politica 40. This distinction corresponds with that of Aristotle in Politeia Book III, ch 4, 107 as well as Book III, ch 13, 129. Also see the views expressed by Malan on citizenship in Politocracy 299-302.

$54 \quad$ Hueglin Early Modern Concepts 123.
} 
provinces could be either secular or ecclesiastical, ${ }^{55}$ that is, an element of the ecclesiastical or the secular constitution. In line with this, Althusius explains that secular political authority does not vest supremely in a single centre. Provinces, like cities, which share divided political authority, contribute to this limitation and therefore to constitutionalism. Althusius explains the relationship between provincial authorities and the imperial authorities (discussed in 2.6.3 below) as follows:

\begin{abstract}
Even though these heads, prefects and rectors of provinces recognise the supreme magistrate of the realm as their superior, from whom their administration and power are conceded, nevertheless they have rights of sovereignty in their territory, and stand in the place of the supreme prince. They prevail as much in their territory as does the emperor or the supreme magistrate in the realm, except for superior pre-eminence, and certain other specifically reserved to the supreme magistrate who does the constituting. ${ }^{56}$
\end{abstract}

\title{
3.3 The realm or universal commonwealth / association
}

The universal association encompassing all the associations thus far discussed is a polity in the fullest sense of the word. This association is the imperium, realm or commonwealth (Althusius is not that much concerned about the exact form of the authority or with the particular person or persons a single monarchical king or a number of polyarchical symbiotes in whom authority vests). ${ }^{57}$ The commonwealth exists on both the ecclesiastical as well as the secular level, but the general principles of the commonwealth obtain to both. The commonwealth is constituted from below, by common agreement of many symbiotic associations and particular bodies. ${ }^{58}$ Thus, cities and provinces oblige themselves to hold, organise, use and defend, through their common efforts, the legal order of the commonwealth. ${ }^{59}$

The members of the commonwealth therefore are the cities and provinces (Althusius adds regions here) who have agreed to constitute the commonwealth, not individuals. Members "(I) say, are not individual men, families or collegia as in a private or particular public association". ${ }^{60}$ The realm is based on consensus and trust, that is, on a tacit and express promise of economic co-operation and counsel under a shared legal order. ${ }^{61}$

\footnotetext{
$55 \quad$ Carney "Translators Introduction" xx.

$56 \quad$ Althusius Politica 62.

$57 \quad$ Althusius Politica 66

$58 \quad$ Althusius Politica 66.

59 Althusius Politica 66. Quite clearly the principle of subsidiarity is once again prominent in this context.

60 Althusius Politica 67. Just as in the case of cities, Althusius makes specific reference to the exclusion of aliens. Althusius Politica 67.
} 
From the outset Althusius takes pains to explain that the authority of the commonwealth is limited, that is, constitutional. Although the authority of the commonwealth is referred to as the supreme authority, such sovereignty is clearly not to be equated with sovereignty in the modern, unbound sense of the word. "(O)wnership" of the realm does not belong to the supreme authority but to the encompassing community; the supreme authority has the authority only to administer. ${ }^{62}$ Althusius, basing his view on Roman law authority and on St Augustine, insists that the supreme authority is under the law (and under religious precepts). If not, the supreme authority is no true authority, more specifically in this case, the king is not a true king, but a tyrant. This view underscores Althusius' subscription to the idea of constitutional government.

The government of the commonwealth is government for the whole; that is, for all the parts of which it is comprised and not only for a particular section. ${ }^{63}$ The very idea of public office, analysed in a discussion of the foundational tenets of Althusius' constitutionalism, ${ }^{64}$ relates to government for the whole and not only for a specific part. The ephors (discussed in 4 below) are a crucial mechanism to secure that government, which has to be in accordance with the law and customs of the commonwealth (including the cities and provinces), is in fact operating for the general public good.

In dealing with the commonwealth Althusius, in line with a long-standing tradition in classical and medieval political thought, ${ }^{65}$ underscores the importance of size or extent. This is crucial for the well-being of the commonwealth since its being either too small or too large may undermine the commonwealth. ${ }^{66} \mathrm{~A}$ commonwealth with a large population is beneficial to fend off external forces and contribute towards its prosperity. On the other hand, however, an overpopulated region or commonwealth can never be free from disadvantages, of which the most important ones could result from a loss of public virtue in a community where wealth is preferred to virtue, bribes to justice, timidity to courage, and evil to good. Too large a population might further lead to over-confidence, folly, contempt and the weakening of the commonwealth. It might also generate an undesirable concentration of power with potentially dangerous consequences for the commonwealth. Power, says Althusius, leads to wealth, to the pursuit of sensual pleasures, and to corruption. "When the might of a commonwealth grows, fortitude and virtue decline." ${ }^{67}$ Having regard to all these considerations, Althusius concludes that

\footnotetext{
62 Althusius Politica 66. The distinction that Althusius makes here is in fact an old one recognised right through medieval thought.

63 Althusius Politica 73.

$64 \quad$ Malan 2017 PELJ $24-26$ (2.4)

65 Aristotle The Politics Book VII ch 4 had already dealt withthis issue.

$66 \quad$ Althusius Politica 68.

67 Althusius Politica 68
} 
a commonwealth of medium size would be the best and steadiest. ${ }^{68}$ He does not elaborate on the ideal size of a commonwealth either in terms of the number of citizens or in terms of geographical area. ${ }^{69}$

\subsection{The ecclesiastical side of the constitutional order}

Althusius' community of piety is also of significance to the "worldly" constitution. He therefore deals at some length with the internal arrangements of the church organisation, which is in part also based on his general federal scheme. I do not deal with these internal arrangements in this discussion. More pertinent for the present discussion is the fact that the office bearers of the church play a part in the worldly constitution in that they serve as an additional check on the exercise of worldly political power, which had to be exercised within the confines of broad religious tenets. In this sense, church office bearers play a role similar to that of the ephors.

This constitutional role of the church dates back to the medieval constitutional practice that originated from the papal revolution of the late eleventh century, in the course of which the secular and ecclesiastical jurisdictions were clearly distinguished and defined. The office-bearers of each were accordingly limited to their respective jurisdictions. This provided for limited government within each jurisdiction and is therefore nothing less than a constitutional measure of the first order. Moreover, the church served as a check on secular government, which had to act within the broad confines of justice and piety, thus further bolstering these constitutional arrangements. ${ }^{70}$

Althusius' thinking is rooted in this tradition. It does not limit constitutional arrangements to the confines of the structures within the power apparatus of the (centralised) territorial state. His constitutionalism involves a variety of power structures in terms of his comprehensive federal order, including the church.

\subsection{The supreme magistrate}

The supreme magistrate is the head of the universal commonwealth, as discussed in 2.5.4. Althusius' discussion of this matter must be seen against the background of the medieval empire, which was headed by the emperor as the supreme magistrate. The adjective "supreme" might give the impression

$68 \quad$ Althusius Politica 69

69 In the present world with a population of more than 7 billion people the achievement of a commonwealth of medium size clearly calls for a new interpretation of the idea of "medium size". Large megacities may be too big to qualify as cities of medium size, unless very innovative constitutional mechanisms are introduced. However, a large number of (non-mega) cities autonomously organised may square with a contemporary interpretation of Althusius' notion of medium size. 
that the (supreme) magistrate - either the single person of the emperor or a collection of persons occupying such an office - possessed unconstrained political power. This impression is understandable, especially if it is based on a modern understanding of supremacy and sovereignty with a possible connotation of unbridled power. It would be entirely wrong, however, to ascribe to Althusius the view that absolute power should be assigned to the supreme magistrate. Absolutism, that is, legally unconstrained political power, was completely alien to the medieval constitutionalism from which Althusius drew inspiration. ${ }^{71}$ The core concepts of Althusian constitutionalism as discussed here, namely the sovereignty of law, popular sovereignty, the covenant, the ephors, and most importantly, the comprehensive federal scheme are all ramparts against unconstrained rule and tend towards constitutional government. They are principles and structures of limited government and for the diffusion, control and balance of power. They represent the direct opposite of absolutism. The classical distinction between the (true) king and the tyrant, to which Althusius subscribed (already referred to above) also reinforced this aversion to absolutism. Moreover, Althusius took aim precisely against those thinkers of his time, namely William Barclay and Jean Bodin, who advocated more absolutist forms of government. ${ }^{72}$ By virtue of his subscribing to popular sovereignty and sovereignty of the law, Althusius emphasises consistently that office-bearers in authority within all the structures of his federal scheme are bound to act under the authority of the commonwealth and the law.

The advice that Althusius gives to public office-bearers, including the supreme magistrate, on how best to govern, provides further support to his balanced constitution, which provides for a variety of power centres within his federal order. Having stated that office-bearers should be treated with respect, Althusius continues as follows:

\section{In his administration of justice the magistrate should always and regularly observe that moderation is exercised, and that the right of each member of the commonwealth is conserved, neither diminished nor increased to the detriment of another. The imperium of the king ought never to be so enlarged that the liberty of the people be suppressed. ${ }^{73}$}

In various other passages Althusius explains that public office-bearers should govern with practical wisdom. As a matter of general principle government should always act in the best interest of the general public good. This, after all, is the hallmark of genuine public office. Public office-bearing should be marked by temperance and due consideration of all relevant factors pertaining to matters that are up for decision. The conduct of public office-bearers should

\footnotetext{
71 See Malan 2015 THRHR 254-259 especially the discussion on sovereignty of the law.

72 See Althusius Politica 71, 72, 105, 130, and 149, 171-174 against Bodin and 109-111, 201 against Barclay.

73 Althusius Politica 175
} 
display a sense of conservatism. They should take heed of how present problems have been dealt with in the past. In the beginning of chapter 21 , titled "Political prudence in the administration of the commonwealth", Althusius refers with approval to the statement by Seneca and to biblical sources and then concludes that office-bearers have to act in a way that has stood the test of time. He refers to Gregorius' De Republica, which states that the good governor will, before making his own decision, consider past events in his own and in other commonwealths to see what was done well and what was done badly. In contrast, bad government is government that fails to take heed of previous experience. Althusius quotes Gregorius as follows:

Most miserable is that commonwealth therefore, in which its governor is imprudent or ignorant in the art of governing, in which he learns for the first ime from his own experience those things that were necessary from the beginning. ${ }^{74}$

Referring to various biblical texts Althusius asserts that God requires for the administration of the commonwealth those who excel in the practice and experience of things. ${ }^{75}$ The good governor must have an understanding of doctrine (doctrina), which basically means knowledge and practice (usus). ${ }^{76}$ Knowledge comes from reading and listening. Reading enables one to learn from the voice of the dead, "(o)r from silent instructors ... principally by the reading of histories". ${ }^{77}$ However, Althusius clearly prefers governors who consult and listen with an open mind as a better way of learning. ${ }^{78}$

\section{The public office of the ephors}

Linguistically the term and the office of the ephors are of Greek origin. ${ }^{79}$ In medieval political thought there are repeated references attesting to the importance of the ephors. ${ }^{80}$ As will be shown in this section, the terms "ephors" refers to a council which assists the supreme magistrate to execute his responsibilities in accordance with the law and the covenant between the commonwealth and the magistrate, and ensures that the authority is exercised to the benefit of the commonwealth. The ephors also serve as a counterbalance of authority and power against the sovereign. In consequence the prevention of any abuse of power to the detriment of any particular community or the commonwealth in general is ensured, and the degeneration of government into tyranny which is harmful to the commonwealth or to any particular community is prevented. Furthermore, government to the sectional gain of only one faction of the commonwealth or to the individual gain of the

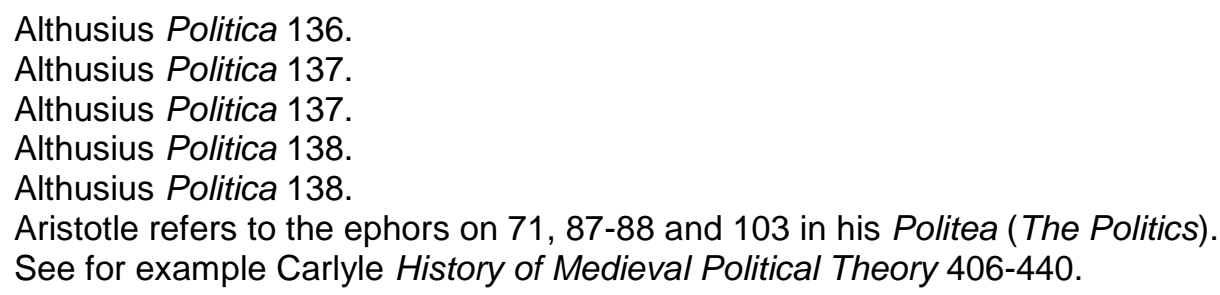


supreme magistrate himself ${ }^{81}$ is also prevented. This responsibility of the ephors highlights their constitutional significance, because constitutionalism can be sustained only when power is contained by counter-power in a system of checks and balances which is an essential part of the notion of constitutionalism, as is outlined at the beginning of this article.

Ephors are representatives of the commonwealth or of communities within the compound commonwealth. Ephors can go by many possible designations depending, among other things, on the constitutional order concerned. They may be referred to as patricians, elders, princes, estates, first citizens or counsellors of the realm, protectors of the covenant, custodians and defenders of the law, justices of the commonwealth, censors of royal honour, brothers of the supreme magistrate, and optimates. ${ }^{82}$ Althusius sets out the powers and responsibilities of the ephors in chapters 18 and 38 of the Politica. In terms of those two chapters the following powers and responsibilities can be extracted:

- They act in the best interest of the commonwealth.

- They constitute the supreme magistrate (general administrator).

- They promote sound governance by articulating the widest variety of views to the benefit of the whole and with due regard to the principle of popular sovereignty.

- They assist and counsel the supreme magistrate.

- They act as a counterbalance to the supreme magistrate by restraining, containing, impeding and correcting the magistrate, and keeping him accountable, and in so doing act as guarantors of constitutional government and as a bulwark against tyranny.

- They act as the custodians, defenders and vindicators of the liberties and rights within the commonwealth.

- $\quad$ (Temporarily) they may act as an interregnum.

- When the supreme magistrate disregards the law and the covenant and descends into tyranny, they resist him and, if required, they legitimately remove him from office. ${ }^{83}$

81 An inquiry into the nature of the responsibilities of the ephors shows that their responsibilities are of a judicial nature - Hueglin Early Modern Concepts 149.

$82 \quad$ Althusius Politica 100, 104.

83 Althusius Politica 91, 99, 103-115, 194-200. 
- There may also be ephors who safeguard the interests of specific communities that is of minorities within the compound commonwealth. ${ }^{84}$

Elaborating on the power and responsibility of containing and restraining the supreme magistrate, it is important to underscore that Althusian constitutionalism, like any fully-fledged cogent constitutionalism, is not only a matter of laudable principles and values discussed above. Neither is it only a question of individual (and communal) rights. In the final analysis, it is also a matter of power, or more specifically, the balance of power. The effective balance of power is required to prevent tyranny, to guarantee government under the law, and to maintain rights. This is the very reason why the ephors are so important. They are entitled to be an effective mechanism of constitutionalism not only because they are obliged to do the right thing but because they command sufficient authority to do so. Althusius expresses this idea as follows:

For great power can not contain itself within boundaries without some coercion and constraint entrusted to others. ${ }^{85}$

The potency of the ephors in the constitutional order is such that without their approval no "enactment or general decree" of the supreme magistrate would be valid. If the counsel of the ephors cannot prevent or mitigate unjust decrees that violate the integrity of the commonwealth or part of it, it is their duty to oppose and impede these decrees. ${ }^{86}$ Althusius expressly rejects the absolutist views of Jean Bodin ${ }^{87}$ as well as those of William Barclay. Alhusius went out of his way to counter Barclay's views. ${ }^{88}$ By exercising their powers in this way the ephors act as a rampart against tyranny and as the keeper of legal and popular sovereignty, because in the final analysis, as the discussion of sovereignty above has shown, political sovereignty vests in the commonwealth and not in the supreme magistrate, a view which Althusius was once again at pains to repeat. ${ }^{89}$ The commonwealth entrusts to the ephors the power to care and defend the commonwealth "(a)gainst all violators, disturbers and plunderers, even against the supreme magistrate himself". ${ }^{90}$ Althusius' views in this regard were clearly formed against the backdrop of his own times, during

$84 \quad$ Hueglin Early Modern Concepts 184, 190.

85 Althusius Politica 104. Carney "Translators Introduction" 21 quite aptly highlights this crucial constitutional truth.

$86 \quad$ Althusius Politica 104.

87 Althusius Politica 105. Also see Hueglin Early Modern Concepts 76. For a discussion of the views of Bodin, see Malan Politiocracy 67-75. Althusius Politica 109-115. William Barclay was a proponent of the theory of the divine right of kings. He is regarded as the most elaborate exponent of that theory. His views were published in 1600. See Sabine History of Political Theory 393. 
which the Habsburg king of Spain (amongst others) was viewed as the violator of the Dutch (part of the) commonwealth. ${ }^{91}$

Ensuing from their power to protect the commonwealth against tyranny, the ephors have the power to resist a supreme magistrate with tyrannical tendencies, that is, a magistrate breaching the law and his covenant with the commonwealth, acting against the general interest and caring only for himself or one section of the commonwealth to the detriment of the rest. In such a case the ephors are duty-bound to act against tyrannical rule. The ephors may do so only in the event of patent misconduct, because as Althusius states in line with the long natural law tradition in medieval political thought, resistance to government is legitimate only when the rulers' actions are repugnant to natural law. ${ }^{92}$ There is therefore no licence for unlawlessness. If governmental conduct is no longer compatible with natural law, it is the duty of the ephors, to depose the ruler concerned. When deposed, the leader is cast out, which, according to Athusius, may in given circumstances entail the death of the tyrant. ${ }^{93}$ The duty of resistance and deposition is the duty of the ephors acting collectively. ${ }^{94}$ It does not fall within the right of the populace to do so of their own accord.

Who then are the ephors? Where do they come from and how are they constituted? In one sense they have always been there as a given of the classical and medieval constitutional tradition. A more detailed answer would be that the ephors, being the defenders of the commonwealth, are constituted by the commonwealth. They are, as Althusius says, elected and constituted by the consent of the commonwealth ${ }^{95}$ or of each relevant community (city or province). They are an incidence of the federal constitutional order, within which political authority is diffused to vest simultaneously in a multitude of centres of power. Ehpors are there by the consent of the tribes, by centurial or curial division (the constitutional structure of the classical polis) and by the votes of the entire people collated through centuries, tribes or collegia in which the people are distributed. However, what is to happen if there are no ephors or if the ephors forsake their responsibilities? This brings us to an entirely different dimension of Althusius' constitutional system, discussed mainly in chapter 38 under the heading, "Tyranny and its remedies". The point of departure is that lax and defaulting ephors or the absence of ephors do not leave the commonwealth without resort, at least not from the point of view of legal and constitutional principle, because sovereignty, in the final analysis, remains vested in the commonwealth, which serves as the residual source

$91 \quad$ Althusius Politica 106.

92 Althusius Politica 119.

93 Althusius Politica 193. This is once again a long-standing notion of medieval constitutionalism which also featured in Calvinist thought, for example in the Vindiciae contra tyrannos. See Sabine History of Political Theory 419.

$94 \quad$ Althusius Politica 193.

$95 \quad$ Althusius Politica 102. 
within the constitutional order. ${ }^{96}$ When there are no ephors to act against tyrannical government, or where the existing ephors desert their duties, there should be special ephors discharging the ephorical constitutional responsibility.

When the ephors do not diligently execute these responsibilities, they are to be held liable and, as Althusius states, may rightly be viewed as betrayers of the commonwealth, "(e)specially when they secretly conspire or connive in the wicked and impious actions of the king". 97 More specifically, when there are no ephors, or if they forsake their responsibilities, the commonwealth or the part within the commonwealth which is left without the protection of the ephors, must elect their own ephors. Then the commonwealth or the affected community of the commonwealth must constitute for themselves ad hoc "public defenders". 98

Althusius has in mind specifically a situation where part of the commonwealth is harmed by tyranny. (Evidently the suggestion was that the Dutch provinces were being harmed by the actions of the tyrannical Spanish king). He states:

These special ephors are obliged to defend only that part of the realm whose care and safety has been entrusted to them but they certainly ought not to abandon the subjects and the region over which they preside unless they first have attempted all legitimate course of action, and have given them up as hopeless... 99

Although Althusius is adamant that the populace may not act on their own and that individual ephors are generally also not entitled to act on their own, a section of ephors emanating from a part of (a distinctive community within) the commonwealth which is injured by tyrannical conduct that cannot pass the test of natural law has the duty to do so, and therefore to lead that part of the commonwealth to what today would be called secession. Thus, Althusius declares:

\begin{abstract}
...one of the ephors may not take imperium away from the magistrate, declare him to be a private person, kill him, resist him beyond the boundaries of this ephor's own territory or of the region assigned to this ephor, or prosecute him...However, it shall be permitted one part of the ream, or individual ephors or estates of the realm, to withdraw from subjection to the tyranny of their magistrate and to defend themselves. ${ }^{100}$
\end{abstract}

A few pages on, Althusius, referring to leading legal publicists as authority elaborated on the question of the right to secession by part of the commonwealth which is faced with tyranny, and then declares:

\footnotetext{
See Althusius Politica 119.

Althusius Politica 101.

Althusius Politica 195.

Althusius Politica 194.

Althusius Politica 194.
} 
One of the estates or one part of the realm, can abandon the remaining body to which it belonged and choose for itself a separate ruler or a new form of commonwealth when the public and manifest welfare of this entire part altogether requires it, or where fundamental laws of the country are not observed by the magistrate but are obstinately and outrageously violated, or when the true worship and the disclosed command of God clearly require and demand that this be done. And this part of the realm can defend by force of arms its new form and status against the other parts of the realm from which it withdrew... Thus also subjects can withdraw their support from a magistrate who does not defend them when he should, and can justly recourse to another prince and submit themselves to him. Or if a magistrate refuses to administer justice, they can resist him and refuse to pay taxes.. ${ }^{101}$

Casey observes insightfully that the quoted stance on secession is premised on Althusius' view of the composition of the political order as an entity consisting of bodies (not individuals). The bodies may break away from the larger body in the event of any breach of the covenant or any harmful or unlawful treatment by government. Individuals cannot secede but bodies can. ${ }^{102}$ This observation brings to light that the notion of the (right to) secession is related to the fundamental conception of the state. The atomist state, that is, the typical Hobbesian state, which is perceived to be a conglomeration of individual atoms, cannot conceive of the idea of secession. In contrast, the composite constitutional order, which is construed on the basis of building blocks of communities, can and does accommodate the notion of secession when one or more building blocks break away.

The office of special ephors for a specific community in the commonwealth which suffers from tyranny (and which is entitled to secede) relates to the accommodation minorities. What is clear is that Althusius' federalism is an important corrective to the majority principle on the basis of individual liberalism, because it acknowledges that the liberty and autonomy of particular communities deserve specific protection and that their interests should not be overridden by the majority. ${ }^{103}$ This would include the protection of cities within the larger federal commonwealth. ${ }^{104}$

This then concludes the discussion of Althusius' constitutionalism as outlined in the Politica, a constitutionalism which in the final analysis amounts to a comprehensive apology for the balanced and mixed constitution ${ }^{105}$ embodied in an encompassing system of republican federalism based on a communitarian view of human life and politics and a keen recognition of all

\footnotetext{
101 Althusius Politica 197-198. Hereafter Althusius once again criticises Barclay's absolutism. See further Hueglin Early Modern Concepts 190-191 on the question of secession.

102 Casey Freedom's Progress 409.

103 Hueglin Early Modern Concepts 109.

104 Hueglin Early Modern Concepts 122, 128.

105 See Heuglin Early Modern Concepts 202-204.
} 
communities within the broad constitutional order that assigns power and authority to the office-bearers of all such communities.

\section{Analysis and conclusion}

Althusius' constitutionalism represents particularity and universality; it maintains a balance of autonomy based on subsidiarity and solidarity. Althusius was strongly influenced by Aristotle but his own particular historic circumstances rendered any comprehensive transplantation of Aristotle's views impossible. The Greek philosophers did not go beyond the homogeneous close-knit unitarian polis. ${ }^{106}$ Neither did Althusius opt for the opposite extreme of medieval and early modern views when the European world "(w)as characterized by a plural maze of interconnected larger and smaller political orders and some, like St. Augustine or Dante, would only see the universal perspective of an empire". ${ }^{107}$ Althusius, however, also opposed Jean Bodin and the successor statist thinkers who accepted the final demise of Christian universality (and a universal empire) and who embraced the idea of the absolute sovereignty of individual territorial states (populated by abstract individual citizens). Althusius, quite differently, as Hueglin puts it:

(t)ried to conceptualize the complex real world of whole and part, universal and particular order, as a many-layered problem requiring a multilevel constitutional solution. On the one hand he could not ignore Bodin's epochal definition of sovereignty any more, since it had already begun to reorganize the modern world of territorial centralization. On the other hand, his entire own social background and theoretical as well as practical motivation did not allow him to abandon the defence of the particular order against the absolute territorial state. He somehow had to find a reconciling compromise between the new principle of territorial sovereignty and the autonomous aspirations of socio-economic, culturalreligious, and territorial minorities. By grafting the principle of sovereignty upon the organized body of the people rather than a state somehow representing individual citizens, he may indeed deserve to be regarded as one of the first early modern theorists of popular sovereignty. By conceptualizing that organized body of the people as a plural and ascending order of power-sharing and co-operation, he very definitely must appear as a theorist of federalism.

The entire political theory of Althusius is characterized by a dialectical relationship of unity and plurality, consociation consociationum. From jurisprudence and theology he borrows the general premise that social life cannot exist without government, and that government (but by no means all forms of social life!) cannot exist without subordination under some ultimate authority. In the same breath he affirms that the generality of this premise must be concretized by a plurality of constitutional arrangements, 'according to the nature and necessity of each consociation'. This is not a juridical differentiation of general norms and particular legal order. Rather, it is something like a constitutional blending of the

\footnotetext{
106 Hueglin Early Modern Concepts 114. For the same reason he could also not follow like theorists such as Marsilius or Machiavelli, because they, as Hueglin Early Modern Concepts 114 puts it, focussed almost exclusively on the existential woes of small city republics; or ssuch as Thomas, who envisioned a world of insular homogeneity. 
Greek ideal of the small autonomous polis, and the Roman concept of universal empire...

Althusius now takes from Aristotle the idea of the polity as the basic constitutional form of political life and aggregates it into the plurality of a compound realm. In doing so, he insists that attributing a definite end to each particular type of assemblage does not mean that there cannot be a common end for all. ${ }^{108}$

The way in which Althusius responded to the challenges of modernization and territorialism was to balance the early modern rise of the territorial state with what he regarded as the need for universal regulation and the continuing tradition of social life in local-regional structures of productive autonomy. In doing so, as Hueglin explained, he sought to preserve the particular identities of regional structures with a new universality of intensified interdependence and efficiency. The product was the first modern theory of federalism. ${ }^{109}$

With the benefit of hindsight there were already strong indications that at the time of the publication of the Politica and notwithstanding all his efforts, Althusius' ideas would soon be overtaken by statism. The advent of the territorial state and the establishment and entrenchment of the paradigm of statism in political and constitutional thought ${ }^{110}$ left no space for Althusius' republican federalism. In recent decades, however, the territorial state has been weakened by potent forces from above and below: from above, mainly by the forces of economic globalisation and universal standards of proper governance; and from below, amongst others, by the forces of cultural, religious and ethnic communities who reject the idea of their own liquidation in order to be remade in the image of the statist Leviathan, and claim instead to be constitutionally accommodated in a way that recognises their distinctive identities and claims to democratic self-governance within a pluralist (poststatist and cosmopolitan) constitutional order. ${ }^{111}$ In step with that, the sway of the statist paradigm has also yielded as crucial concepts of politics and constitutional law are increasingly reconceived in a non-statist and post-statist way. This post-statist mode of thinking can arguably be described as politocratic, a term that suggests, amongst other things, that:

power should be vested in a multitude of centres and not only in the government of the centralised territorial state; and

- that citizenship which in the massocratic megalopolis ${ }^{112}$ (the large territorial state) has shrunk to barely more than a formal legal status, could be reinvigorated so as to denote actual participation in self-

\footnotetext{
108 Hueglin Early Modern Concepts 114-115.

109 Hueglin Early Modern Concepts 132-133.

110 On this topic in general see Malan Politocracy ch 3, 4 and 6.

111 See for example Cable 1995 Daedalus 23, Strange 1995 Daedalus 56.

112 To use the apt terms of Sartori Democratic Theory 21.
} 
government, which to my mind is achievable only within a politocratic political order. ${ }^{113}$

It is against this backdrop that Althusius' views are now regaining the ground they lost centuries ago and are growing in importance in present-day political and constitutional theory. Just as it was not possible for Althusius simply to apply Aristotle's views in the circumstances of his time, it is also impossible for us to apply Althusius' views in present-day conditions. Past theories, as Hueglin aptly stated: "(d)o not provide ready blueprints for the explanation of the present world, nor for alternative constructions". ${ }^{114}$ Past theories can, however, be instructive "(a)s a reservoirs of ideas allowing for a comparative exploration of similar and analogous positions of theory and practice across time."115 In this way the past is not a closed, inaccessible book which is completely locked away from us. It is our inheritance, the body of our experience, the living tradition of our collective memory, that can inform us and from which we can benefit and upon which we can build". ${ }^{116}$

The Politica relays Althusius' interpretation and defence of the late medieval political order of Western Christianity - Western Europe. No doubt the interpretation is somewhat idealistic, as Althusius does not concede any shortcomings in the system. That is why it is regarded as an interpretation and not merely a description. Althusius gives an account of a constitutional dispensation, in part based on historical experience and firmly supported by "sacred and profane" biblical, theological and philosophical examples and juridical authority, which he presents as the ideal constitutional order.

There are many crucial present-day issues that Althusius did not deal with, issues that gain importance only in times after Althusius. Most importantly, individual rights, which are enjoying centre stage in present-day constitutional thinking and practice, did not feature in Althusian thinking, at least not under the present-day designations of constitutional, fundamental, basic or human

113 By this is meant a politico-constitutional order of multispherical government by the citizens of every political community over the specific res publica - the commonwealth - of the relevant community, as discussed in ch 10; more specifically at 299 et seq of Malan Politocracy. The views on citizenship that I advocated there correspond with those of Althusius, summarised as follows by Hueglin Early Modern Concepts 234: "By organising active citizenship in an ascending order of cumulative consociation held together by fundamental laws established and shared on the basis of consent and solidarity, the Althusian commonwealth foreshadows a cosmopolitan construction of politics in which 'People would come ...to enjoy multiple citizenships - political membership in the diverse political communities which significantly affected them. They would be citizens of their immediate communities, and of the wider regional and global networks which impact upon their lives'".

114 Hueglin Early Modern Concepts 269.

115 Hueglin Early Modern Concepts 198.

116 This is how Edmund Reflections viewed the past. His entire work speaks of this approach but see specifically 117, 192, 196, 267, 282 and 305. 
rights. ${ }^{117}$ At present it is impossible to conceive of any constitutional dispensation in which these rights are not prominently accounted for. The absence of this theme in Althusian constitutionalism is one of several reasons why it is impossible to simply transplant Althusian thinking into our present-day world.

There is another reason why Althusian thinking does not lend itself to such transplantation, which is that in pre-modern natural-law thinking, to which Althusius still mainly subscribes, society is viewed as essentially a fixed order, that is, a naturally and divinely ordained order which is not susceptible to fundamental change. The tumultuous social and political historical events that have since occurred over many centuries belie any belief in the natural permanence of socio-political realities. Political and constitutional thinking proceeding strictly from the static premise inherent in such belief has forfeited credibility and lost the appeal it once had.

Statism, however, is also not a natural and unchangeable given. In the face of the descent of statism it is informative and therefore relevant to consider past thinking, which, if freely (instead of fundamentally) interpreted and judiciously utilised, may prove to give valuable pointers to the future. It is in this context that Althusius enters the present-day stage.

I highlight only the two aspects of Althusian constitutionalism which are arguably most important for constitutional thinking in the present and a future age. The first is an anthroplogical aspect and the second relates to state departmentalisation.

\subsection{An anthropological odservation}

In the first part of this discussion it was pointed out that statist constitutionalism recognises only two entities, namely the state and the individual, and that statist constitutionalism provided a framework for centralisation and, more importantly, for homogenization, in that everybody within the territorial state is to be remade in the image of the statist Leviathan, which in practical terms means in the image of the dominant community in the population of the state concerned. On close analysis, statist constitutionalism is premised on an abstract anthropology that views human beings in extremely generalised terms. All people are viewed as being basically the same. The differences between them are so negligible that they can be ignored in political and constitutional theory and can be disregarded when devising a constitution.

117 Designations such as constitutional, fundamental, basic or human rights. Basic freedoms were in a process of being acknowledged, as in the interdictum de homine liberum exhibendum and the writ of habeas corpus. Fully-fledged sets of basic rights came to be recognised only in the French and American Revolutions and then finally after World War II. 
Since there are no notable differences between them, people are not to view themselves from a community perspective. Humankind is not seen as a collection of communities, nor as individuals belonging to a collection of communities, but simply as an aggregate of (abstract) individuals. In this regard Locke considers the state to be an aggregate of persons or, as he puts it, any number of men, and not the politico-constitutional apparatus of one or more communities. ${ }^{118}$ It is also on that score that modernist social contract theories, which are as distant from one another as the theories of Hobbes and John Rawls, can be seen to be based on the same premise of the universalised abstract individual. ${ }^{119}$

Implicit in Althusius' thinking is a totally different anthropology. Although there might be general proclivities (such as the human urge for creating and maintaining community life), humankind is not made up of abstract individuals who are fundamentally the same as all other abstract individuals. Human beings are specified particularly in the sense that they belong to and that their identities, outlook and way of life are shaped by communities - cultural, linguistic, religious, local and others. There is an inherent value in all these communities. All are worthy of recognition and protection because they are valuable to the people who belong to them. It is of even greater importance to understand that all communities together, each with its distinctive characteristics, makes its own unique contribution towards constituting the totality of mankind, that is, to universal humanity. ${ }^{120}$ If any one of these communities is destroyed or assimilated with another, or prevented from being part of universal humanity, two things occur simultaneously. Firstly, a mischief, even a crime, against the community concerned is committed. Secondly, it is a wrong perpetrated against the totality of humankind. Precisely for that reason it is apt to view genocide as a crime against humanity. We therefore have what we may call a germinating law of inter-communal relations, ${ }^{121}$ which prohibits not only genocide but arguably also hate speech. In consequence, the integrity of the community is protected and not in the first place that of individual members of the community.

118 It is also as a result of this that Friedrich Man and his Government 547 quite aptly made the observation that the building of the modern state preceded the building of the nation (the statist nation, of course).

119 It is also to be noted that Rawls also shared with Hobbes the same statist premise. See the discussion in Malan Politicracy 155-163.

120 The insights of the late eighteenth century German philosopher, Johann Gottlfried Herder are particularly instructive in this context. Herder's view of the universal humanity constituted by the indispensable contribution of each cultural community made him a staunch opponent of colonialism since that was an assault on the variety of communities and an impoverishment of the universal Humanität. See the discussion of Barnard Herder's Social and Political Thought 97 et seq. On this issue, see the discussion in Malan 2014 De Jure 231-257. 
Due to its abstract anthropology, statism lacks a sense of a community-based universal humanity. It is preoccupied with abstract individuals - any number of men - within the (abstract) space of the territorial state, which during the nineteenth and more specifically the twentieth century led to the destruction of many cultural communities within (erstwhile) multicultural territorial states. Frightened by this destruction, the past decades have seen the emergence of minority rights. That is a favourable development far from an adequate guard against the destructive logic of statism. It is inadequate because the rights (reluctantly, from a statist perspective) afforded to communities (or rather, to individual members of communities ${ }^{122}$ ) are adjudicated by statist judiciaries. It does not vest communities with the powers of autonomous government. The rights of minorities therefore remain within the paradigm of statism. What is therefore required is that communities should also be vested with powers of self-governance, thus doing away with undivided state sovereignty and the vitriolic consequences of statist homogenisation. This implies a macro-federal constitutional order in which the totality of particular communities as well as universal humanity enjoy recognition. This is an order that might be described as politocratic. It denotes the dispensation of multispherical government by the citizens of every political community, from the smallest habitative community to the largest universal community, by the relevant citizens of each community over the specific common goods (res publica/commonwealth) of each community. ${ }^{123}$ Althusius' federalism, based on his concrete communitarian outlook, in contrast to a generalised abstract anthropology as outlined in his Politica, provided the framework for such post statist politicratic constitutionalism.

\subsection{State-departmentalisation}

Present-day (statist) constitutionalism is essentially state-departmentalised. The structures that it provides for the checking and controlling of power and for guarding against power abuse are all structures 0 , and within the same power apparatus of the state in question. The doctrine of the separation of powers with its "independent and impartial" judiciary augmented by a raft of other so-called independent and impartial constitutional bodies such as public protectors, ombuds, independent and impartial judicial service commissions, auditors general, prosecutorial authorities and a panoply of other seemingly independent and impartial constitutional bodies, are all integral elements of one and the same state structure and in the final analysis constituted and

122 The wording of article 27 of the International Covenant of Civil and Political Rights (ICCPR) demonstrates this point. Rights under this provision accrue to the members of minorities, not the communities as such. Lately, however, the provision has been generously interpreted so as to expand protection also to communities.

123 Malan Politocracy 272. The concept of habitative communities, the smallest local and cultural communities, is explained in Politocracy xi and ch 10. 
conditioned by a single power elite under the control of a single centralised centre of political power. Regardless of their formal separation and their formal independence and impartiality, these powers, institutions and bodies are in the final analysis tied together in a single power structure under the control of the leading force within such a state. They therefore assume the character of state departments under the direct control of the dominant political power in the legislature and the executive. It is precisely for this reason that I posit that our dominant constitutional thinking and practice essentially provide for statedepartmentalisation.

In substantive terms such state-departmentalisation falls far short of providing for the real separation of powers and checks and balances. Instead it establishes a unitary power system. By the same token, these institutions are dependent on the leading political forces in the legislature and the executive and are biased in their favour, in spite of the formal appearance of independence and impartiality. ${ }^{124}$ Appointments to these institutions are determined by a single power centre which is dominant in the legislature and the executive (and emanates from the ruling political party.) Whilst this state of affairs is kept in check in a system where there are regular changes in government, state-departmentalisation is acutely harmful in a system dominated by one party, such as South Africa. ${ }^{125}$ This is not to say that there is altogether no value in these institutions. They do have a role to play. The inherent weakness of this state-departmentalisation can, however, be denied or ignored only on pain of a serious loss of real constitutional quality in the constitutional order. Such order might eventually have the charming appearance of constitutionalism, yet be devoid of the substantive characteristics of constitutionalism in the sense that there are no real checks and balances, which are an essential element of constitutionalism, as concisely explained at the beginning of the article.

If the structures of constitutionalism are state-departmentalised and therefore controlled by a single centralised source of power, (mutual) checks, controls, balances and limitation of power are fatally flawed. Then remains but the hope that the single source of power will constrain itself. That hope, however, does not spring from the existence of the necessary structures of constitutionalism but from the opposite, namely from its demise.

A multitude of sources of power in a relationship of mutual balance can be sustained only if each within that variety is rooted in its own communal identity and is keen to rule itself, each in its own distinctive way. If communities,

\footnotetext{
124 See Malan 2014 PELJ 1965-2040.

125 This is how South Africa is now viewed by various observers in political science and in public law. See for example Giliomee, Myburgh and Schlemmer 2001 Democratization 161-182; Southall 2005 Africa Spectrum 61-82; Choudhry 2009 CCR 5-19.
} 
conscious of their distinctive identities and interests, are absent, the impetus for self-government would obviously also be absent and then there cannot be a dispensation comprising a multitude of centres of power, which is the first prerequisite for constitutionalism based on mutual checks, balances, controls and the limitation of power. A multitude of different communal identities is therefore the essential life blood for a multitude of centres of political power and authority for constitutionalism. That is what fertilises the ground for constitutionalism. Without it the chances for genuine constitutionalism are slender at best.

It is against this background that the programmes of homogenisation referred to above, which are so prominent within statist theory and practice, should be viewed. Homogenisation kills the multitude of communal identities and also the urge for self-government. In consequence any possibility of a multitude of centres of power, which is the first and essential prerequisite for constitutionalism, will fall away. From a constitutional point of view, these programmes should be viewed with utter disdain, because without the heterogeneity sustained by a multitude of communities and centres of selfgovernment, constitutionalism is gravely imperilled. Without that, constitutionalism wastes away to an impoverished order of statedepartmentalisation. In the modern centralised and homogenised territorial state, constitutionalism struggles to be more than that. Althusius' republican federalism can help to show the way to a better and more genuine constitutionalism beyond the constraints of statism.

\section{Bibliography}

\section{Literature}

\section{Althusius Politica}

Althusius J Politica: Politics Methodically Set Forth and Illustrated with Sacred and Profane Examples (an abridged and translated version edited and translated from Latin by FS Carney) (Liberty Fund Indianapolis 1994)

Aristotle The Politics

Aristotle The Politics (translated from Greek by TA Sinclair) (Penguin Middlesex 1962)

Barnard Herder's Social and Political Thought

Barnard FM Herder's Social and Political Thought from Enlightenment to Nationalism (Clarendon Press London 1965)

Berman Law and Revolution

Berman HJ Law and Revolution: The Formation of the Western Legal Tradition (Harvard University Press Massachusetts 1983) 
Burke Reflections

Burke E Reflections on the Revolution in France (Penguin Middlesex 1968)

Cable 1995 Daedalus

Cable V "The Diminished Nation State: A Study in the Loss of Economic Power" 1995 Daedalus 23-54

Carlyle History of Medieval Political Theory

Carlyle AJ A History of Medieval Political Theory in the West Vol III; Vol VI (Blankwood London 1928)

Carney "Translators Introduction"

Carney FS "Translators Introduction" in Althusius $\mathrm{J}$ Politica: Politics Methodically Set Forth and Illustrated with Sacred and Profane Examples (an abridged and translated version edited and translated from Latin by FS Carney) (Liberty Fund Indianapolis 1994) ix-xxxiii

Casey Freedom's Progress?

Casey R Freedom's Progress? A History of Political Thought from the Perspective of Liberty (Imprint Academic Exeter 2017)

Choudhry 2009 CCR

Choudhry S "'He had a Mandate': The South African Constitutional Court and the African National Congress in a Dominant Party Democracy" 2009 CCR 186

De Benoist 2000 Telos

De Benoist A "The First Federalist: Johannes Althusius" 2000 Telos 25-58

De Tocqueville Ancient Regime

De Tocqueville A The Ancient Regime and the Revolution (Penguin London 2008)

Diamond "Rule of Law"

Diamond S "The Rule of Law versus the Order of Custom" in Wolff RP (ed) The Rule of Law (Simon and Schuster New York1971) 115-144

Elazar "Althusius's Grand Design"

Elazar DL "Althusius's Grand Design for a Federal Commonwealth" in Althusius J Politica: Politics Methodically Set Forth and Illustrated with Sacred and Profane Examples (an abridged and translated version edited and translated from Latin by FS Carney) (Liberty Fund Indianapolis 1994) xxxv-xlvi

Friedrich Man and his Government

Friedrich CJ Man and his Government: An Empirical Theory of Politics (McGraw-Hill New York 1963) 
Giliomee, Myburgh and Schlemmer 2001 Democratization

Giliomee H, Myburgh $\mathrm{J}$ and Schlemmer L "Dominant Party Rule, Opposition Parties and Minorities in South Africa" 2001 Democratization 161-182

Hueglin Early Modern Concepts

Hueglin TO Early Modern Concepts for a Late Modern World - Althusius on Community and Federalism (Wilfred Laurier University Press Waterloo, Ontario 1999)

Locke Of Civil Government

Locke J Of Civil Government: The Second Treatise (Wildside Rockville 2008)

Malan Politocracy

Malan K Politocracy: An Assessment of the Coercive Logic of the Territorial State and Ideas around an Answer to It (Pretoria University Law Press Pretoria 2012)

Malan 2014 De Jure

Malan K "The Suitability and Unsuitability of Ubuntu in Constitutional Law Inter-communal Relations versus Public Office-bearing" 2014 De Jure 231257

Malan 2014 PELJ

Malan K "Reassessing of Judicial Independence and Impartiality against the Backdrop of Judicial Appointments in South Africa" 2014(17)5 PELJ 19652040, available at http://dx.doi.org/10.4314/pelj.v17i5.05

Malan 2014 Tydskr Geesteswet

Malan K "Taalverval met Besondere Verwysing na die Ideologieë en Praktyke van Verstaatliking" 2014 Tydskr Geesteswet 462-480

Malan 2015 THRHR

Malan K "Die Dinamika van die Hedendaagse Oppermagtige Grondwet Beskou in die Lig van Voor- en Vroeg-Moderne Opvattings oor Regsoppergesag en Populêre Soewereiniteit" 2015 THRHR 248-266

Malan 2017 PELJ

Malan K "The Foundational Tenets of Johannes Althusius' Constitutionalism" 2017(20) PELJ http://dx.doi.org/10.17159/1727-3781/2017/v20i0a1344

McRae 1979 CJPS

McRae K "The Plural Society and the Western Political Tradition" 1979 CJPS 575-688 
Nisbet Quest for Community

Nisbet R The Quest for Community: A Study in the Ethics of Order and Freedom (ICS Press San Francisco 1990)

Pennington Seventeenth Century Europe

Pennington DH Seventeenth Century Europe (Longman London 1970)

Pestieau 1991 Can J Law Jurisprud

Pestieau J "Minority Rights: Caught between Individual Rights and Peoples' Rights" 1991 Can J Law Jurisprud 361-373

Sabine History of Political Theory

Sabine GH A History of Political Theory (Harrap London 1971)

Sartori Democratic Theory

Sartori G Democratic Theory (Wayne State University Press Detroit 1962)

Skinner "The State"

Skinner Q "The State" in Ball T et al (eds) Political Innovation and Conceptual Change (Cambridge University Press Cambridge 1989) 90-131

Southall 2005 Africa Spectrum

Southall R "The 'Dominant Party Debate' in South Africa" 2005 Africa Spectrum 61-82

Strange 1995 Daedalus

Strange S "The Defective State" 1995 Daedalus 55-74

Van Dyke 1974 Am J Pol Sci

Van Dyke V "Human Rights and the Rights of Groups" 1974 Am J Pol Sci 725741

Van Dyke 1976-77 World Politics

Van Dyke $V$ "The Individual the State and Ethnic Communities in Political Theory" 1976-77 World Politics 343-369

\section{List of Abbreviations}

$\begin{array}{ll}\text { Am J Pol Sci } & \text { American Journal of Political Science } \\ \text { Can J Law Jurisprud } & \text { Canadian Journal of Law and Jurisprudence } \\ \text { CCR } & \text { Constitutional Court Review } \\ \text { CJPS } & \text { Canadian Journal of Political Science } \\ \text { ICCPR } & \text { International Covenant of Civil and Political } \\ & \begin{array}{l}\text { Rights } \\ \text { PELJ }\end{array} \\ \text { Potchefstroom Electronic Law Journal }\end{array}$


THRHR

Tydskr Geesteswet
Tydskrif vir Hedendaagse Romeins-Hollandse Reg

Tydskrif vir Geesteswetenskappe 